\title{
Latent lymphocytic enterocolitis associated with celiac disease manifesting after resection for colon cancer: Case report and review of the literature
}

\author{
Vikram Tangri MD ${ }^{1}$, David K Driman MBChB FRCPC ${ }^{2}$, Nilesh Chande MD FRCPC ${ }^{3}$
}

\begin{abstract}
V Tangri, DK Driman, N Chande. Latent lymphocytic enterocolitis associated with celiac disease manifesting after resection for colon cancer: Case report and review of the literature. Can J Gastroenterol 2008;22(9):771-773.

Lymphocytic colitis, a cause of chronic watery diarrhea, is histologically characterized by increased intraepithelial lymphocytosis. Studies have associated this disorder with celiac disease, although there are no reports of patients with both lymphocytic colitis and colon cancer. The present case report describes a patient with lymphocytic colitis, which manifested five years after he presented with a cecal adenocarcinoma, and three years following a diagnosis of celiac disease. Pathological review of his initial resection specimen demonstrated lymphocytic enterocolitis, indicating a five-year latency in the presentation of this disease.
\end{abstract}

Key Words: Celiac disease; Colitis; Colorectal cancer; Lymphocytic colitis; Microscopic colitis

\section{Entérocolite lymphocytaire latente associée à la maladie coeliaque se manifestant après résection d'un cancer du côlon : Rapport de cas et revue de la littérature}

\begin{abstract}
La colite lymphocytaire, une cause de diarrhée aqueuse chronique, se caractérise sur le plan histologique par une lymphocytose intra-épithéliale accrue. Des études ont établi un lien entre cette maladie et la maladie cœliaque, bien qu'aucun cas de colite lymphocytaire et de cancer du côlon concomitants n'ait été rapporté. Le présent article décrit un patient atteint d'une colite lymphocytaire qui s'est manifestée cinq ans après un adénocarcinome au niveau du cæcum et trois ans après un diagnostic de maladie cœliaque. L'analyse pathologique du premier spécimen réséqué a révélé la présence d'une entérocolite lymphocytaire, indiquant une latence de cinq ans avant l'apparition de signes de cette maladie.
\end{abstract}

Tymphocytic colitis is a cause of chronic watery diarrhea, Land is characterized by histological abnormalities in endoscopically normal colonic mucosa (1). It is related to collagenous colitis, with both disorders having similar clinical presentations but distinct histological features (2). These conditions are collectively referred to as microscopic colitis. The predominant finding in lymphocytic colitis is increased intraepithelial lymphocytosis, while collagenous colitis has a thickened subepithelial collagen band $(2,3)$.

A higher prevalence of lymphocytic colitis in women has been reported $(4,5)$, and the diagnosis is usually made in middle or old age (6). Clinically, lymphocytic colitis may present with diarrhea and abdominal cramping, nausea, fatigue and weight loss $(6-8)$. Both the etiology and pathogenesis of this illness remain unknown, although autoimmune and drugrelated causes have been proposed $(6,8-11)$. Studies $(12,13)$ have linked lymphocytic colitis with celiac disease, while others $(14,15)$ have proposed an association between collagenous colitis and colorectal cancer. Currently, little is known about the link between lymphocytic colitis and colorectal cancer.

\section{CASE PRESENTATION}

An 81-year-old man presented initially for assessment of anemia, weight loss and mild diarrhea. His medical history included gastroesophageal reflux disease, osteoarthritis, benign prostatic hypertrophy, hypertension and stroke, as well as longstanding lactose intolerance for which he was taking a lactosefree diet. Colonoscopy performed at that time demonstrated a stage 2 cecal adenocarcinoma. He underwent a right hemicolectomy and, postoperatively, his diarrhea and other symptoms completely resolved.

Two years later, the patient presented with watery diarrhea occurring three times daily and mild weight loss. Colonoscopy and subsequent small bowel and sigmoid biopsies were negative. His antitransglutaminase antibody was positive at $1768 \mathrm{U} / \mathrm{mL}$ (normal is less than $6.0 \mathrm{U} / \mathrm{mL}$ ), and small bowel biopsies at upper endoscopy demonstrated flattened villi and increased intraepithelial lymphocytosis typical of celiac disease (Figure 1), along with lymphocytic gastritis (Figure 2). A gluten-free diet led to resolution of his diarrhea and allowed him to regain his lost weight.

Surveillance colonoscopy, performed five years after the resection, demonstrated a small hyperplastic polyp at the transverse colon but no cancer recurrence. His current assessment was for new-onset watery diarrhea, occurring three to four times per day for approximately one year. This condition was associated with urgency, nocturnal stools, abdominal cramping, nausea, mild weight loss and fatigue, and persisted for nearly one year despite strict adherence to his gluten- and lactose-free diet. His medications at this time included amlodipine, ramipril and acetylsalicylic acid, without any recent changes. He was given a prescription for loperamide $2 \mathrm{mg}$ orally, as needed. $\mathrm{He}$ was also prescribed oral rabeprazole $20 \mathrm{mg}$ daily for his gastroesophageal reflux disease. Colonoscopy was performed one month later, and biopsies from his ileum and colon demonstrated lymphocytic enterocolitis (Figure 3). His symptoms

${ }^{1}$ Faculty of Medicine and Dentistry; ${ }^{2}$ Department of Pathology; ${ }^{3}$ Department of Medicine, Division of Gastroenterology, The University of Western Ontario, London Health Sciences Centre, London, Ontario

Correspondence: Dr Vikram Tangri, clo Dr Nilesh Chande, Mailbox 55, London Health Sciences Centre, South Street Hospital, 375 South Street,

London, Ontario N6A 4G5. Telephone 519-667-6582, fax 519-667-6820, e-mail vtangri2008@meds.uwo.ca

Received for publication April 11, 2008. Accepted April 13, 2008 


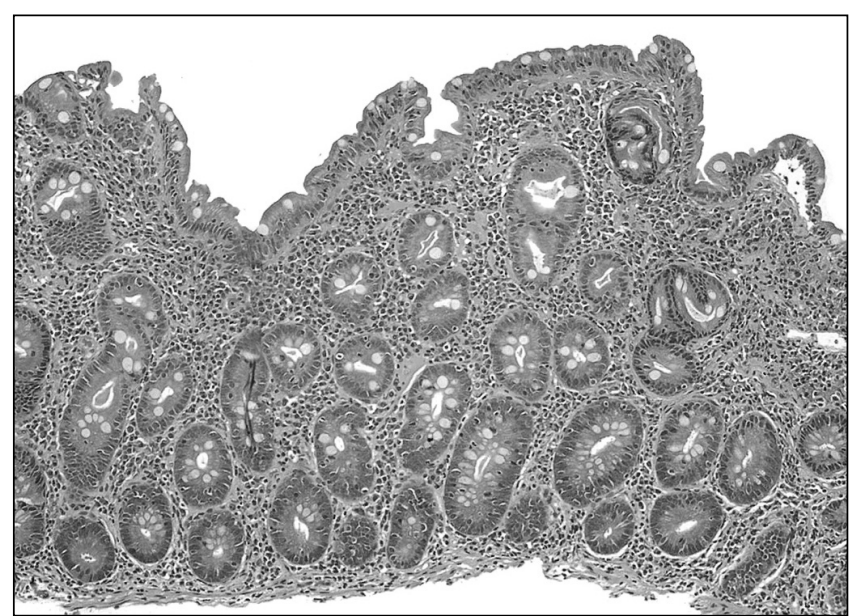

Figure 1) Celiac disease - the duodenal mucosa shows blunted villi, increased numbers of inflammatory cells in the mucosa and increased intraepithelial lymphocytes

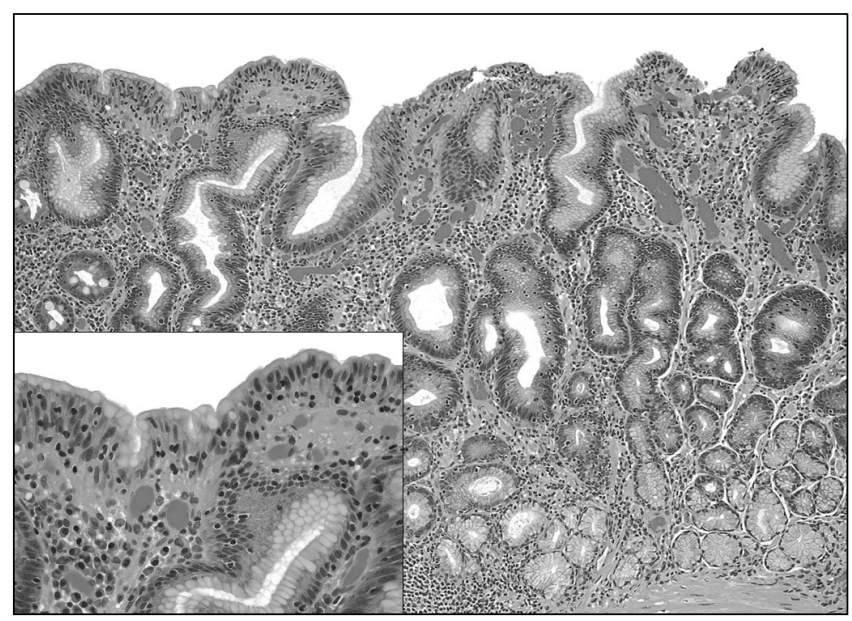

Figure 2) Lymphocytic gastritis - there is a marked increase in the number of intraepithelial lymphocytes in the gastric foveolar epithelium. Inset - higher magnification of intraepithelial lymphocytes

responded partially to loperamide treatment over the subsequent three months, at which point, cholestyramine $4 \mathrm{~g}$ daily was added to his medical therapy.

Pathological review of the specimen from his initial colon cancer resection six years earlier demonstrated findings of lymphocytic enterocolitis (Figure 4); the degree of inflammation was lower than in his most recent biopsies.

\section{DISCUSSION}

Lymphocytic colitis usually presents in middle- or older-aged adults (6). Studies $(6,9,16-19)$ report a female predominance, with female to male ratios ranging from $5.75: 1$ to $1: 1$. Studies $(6,10,20)$ have shown a link between a variety of drugs (eg, nonsteroidal anti-inflammatory drugs, lansoprazole) and lymphocytic colitis.

Familial occurrences of lymphocytic colitis have been reported (21), in addition to associations with thyroid disorders, diabetes mellitus, inflammatory bowel disease and others $(4,9,18,20)$. Celiac disease has been found in $6 \%$ to $27 \%$ of patients with lymphocytic colitis $(5-6,18,22)$. This relationship

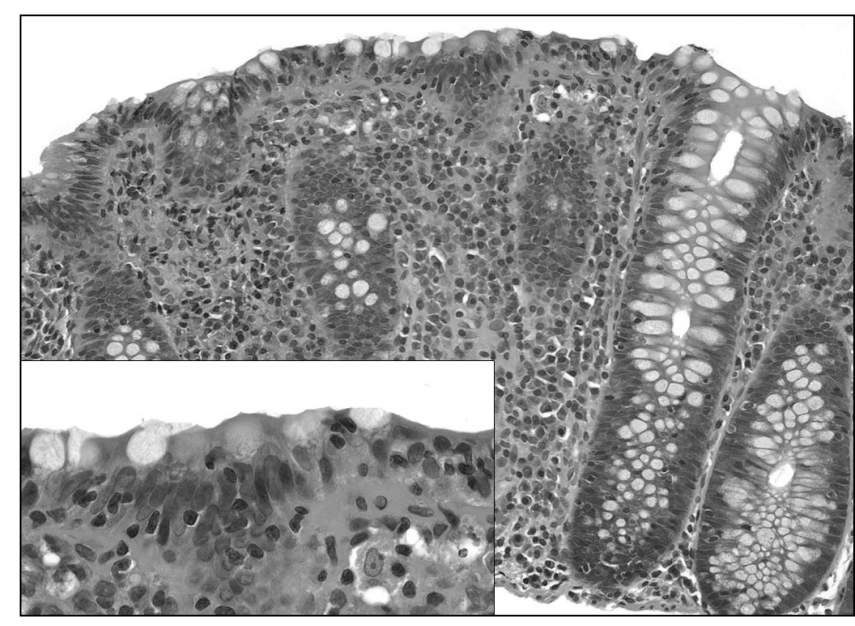

Figure 3) Lymphocytic colitis (biopsies at recent presentation) colonic mucosa contains an increased number of mucosal plasma cells and increased intraepithelial lymphocytes. Inset - higher magnification of intraepithelial lymphocytes

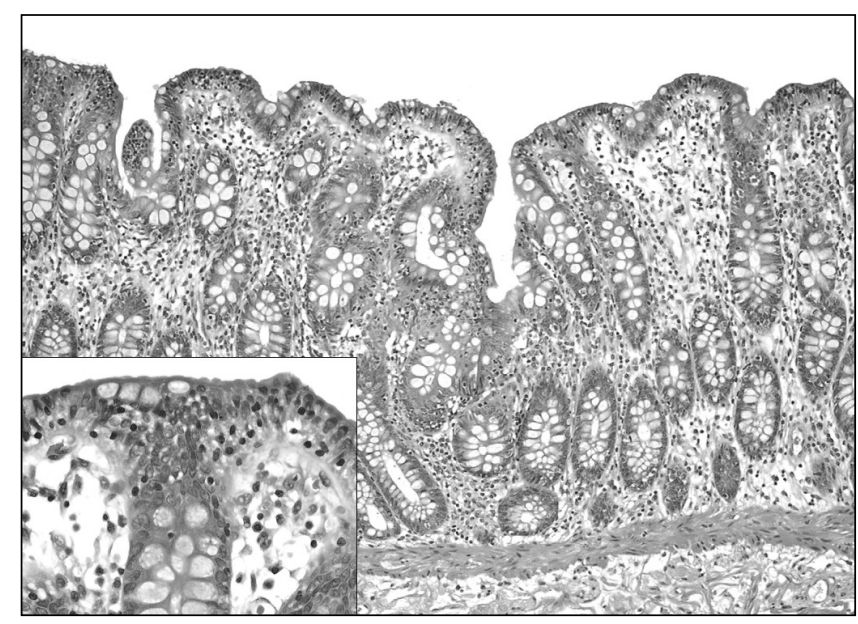

Figure 4) Lymphocytic colitis (from colon cancer resection specimen) - colonic mucosa with increased intraepithelial lymphocytes but fewer mucosal plasma cells than in the subsequent biopsies. Inset higher magnification of intraepithelial lymphocytes

may be mediated by shared haplotype HLA DQ2 $(12,23)$, although this haplotype was not increased in patients with lymphocytic colitis in another study (4). In one study (24), lymphocytic gastritis was found in $33 \%$ of patients with celiac disease, and lymphocytic colitis was found in $38 \%$ of those with both celiac disease and lymphocytic gastritis (24).

Although cases of celiac disease with coexistent colon carcinoma have been reported (25), studies have not shown an increased incidence of colorectal neoplasms in patients with celiac disease; nevertheless, colonoscopic evaluation for possible neoplasm in patients with iron deficiency anemia is an important investigation $(26,27)$.

We performed a PubMed literature search for case studies published between 1980 and August 2007 that described lymphocytic or collagenous colitis associated with colorectal cancer. We also examined review papers of microscopic colitis published in the same period. There were no reports of an association between lymphocytic colitis and colorectal cancer. Although some studies $(28,29)$ demonstrated no increased risk of cancer in patients with collagenous colitis, 
there were three case reports of collagenous colitis associated with colon cancer. Two of these $(14,30)$ described collagenous colitis associated with colon cancer in female patients in their seventh decade of life. Another (15) showed both symptomatic and histological resolution of collagenous enterocolitis in a 52-year-old woman after surgical intervention for localized colon cancer, and suggested that this was a paraneoplastic phenomenon.

The present paper describes an 81-year-old man with latent lymphocytic enterocolitis. After the initial presentation, he remained asymptomatic from this disease before developing a one-year history of diarrhea and associated symptoms. A comparison of biopsy specimens from his most recent colonoscopy with previous biopsy specimens showed changes in lymphocytic enterocolitis.

Because the course of lymphocytic colitis is uncertain, and may worsen or resolve on its own (8), it is possible that it may have contributed to his initial presentation when diagnosed with colon cancer, as well as his presentation four years later when he was diagnosed with celiac disease. Nonetheless, his symptoms in both cases resolved with surgery and a gluten-free diet, respectively. The present case demonstrates an apparent five-year latency in the presentation of lymphocytic enterocolitis.

\section{REFERENCES}

1. Lazenby A, Yardly JH, Giardiello FM, Jessurun J, Bayless TM. Lymphocytic ("microscopic") colitis: A comparative histopathologic study with particular reference to collagenous colitis. Hum Pathol 1989;20:18-28.

2. Bohr J, Olesen M, Tysk C, Jarnerot G. Collagenous and lymphocytic colitis: A clinical and histopathological review. Can J Gastroenterol 2000;14:943-7.

3. Giardiello FM, Lazenby AJ. The atypical colitides. Gastroenterol Clin North Am 1999;28:479-90.

4. Giardiello FM, Lazenby AJ, Bayless TM, et al. Lymphocytic (microscopic) colitis. Clinicopathologic study of 18 patients and comparison to collagenous colitis. Dig Dis Sci 1989;34:1730-8.

5. Olesen M, Eriksson S, Bohr J, Järnerot G, Tysk C. Microscopic colitis: A common diarrhoeal disease. An epidemiological study in Örebro, Sweden, 1993-1998. Gut 2004;53:346-50.

6. Chande N, Driman DK, Reynolds RP. Collagenous colitis and lymphocytic colitis: Patient characteristics and clinical presentation. Scand J Gastroenterol 2005;40:343-7.

7. Fernandez-Banares F, Salas A, Esteve M, Espinos J, Forne M, Viver JM. Collagenous and lymphocytic colitis. Evaluation of clinical and histological features, response to treatment, and long-term follow-up. Am J Gastroenterol 2003;98:340-7.

8. Pardi DS, Smyrk TC, Tremaine WJ, Sandborn WJ. Microscopic colitis: A review. Am J Gastroenterol 2002;97:794-802.

9. Olesen M, Eriksson S, Bohr J, Jarnerot G, Tysk C. Lymphocytic colitis: A retrospective clinical study of 199 Swedish patients. Gut 2004;53:536-41.

10. Beaugerie L, Pardi DS. Review article: Drug-induced microscopic colitis - proposal for a scoring system and review of the literature. Aliment Pharmacol Ther 2005;22:277-84.

11. Chande N, Driman DK. Microscopic colitis associated with lansoprazole: Report of two cases and a review of the literature. Scand J Gastroenterol 2007;42:530-3.

12. Fine KD, Do K, Schulte K, et al. High prevalence of celiac sprue-like HLA-DQ genes and enteropathy in patients with the microscopic colitis syndrome. Am J Gastroenterol 2000;95:1974-82

13. Matteoni CA, Goldblum JR, Wang N, et al. Celiac disease is highly prevalent in lymphocytic colitis. J Clin Gastroenterol 2001;32:225-7.

14. Gardiner GW, Goldberg R, Currie D, Murray D. Colonic carcinoma associated with an abnormal collagen table. Collagenous colitis. Cancer 1984;54:2973-7.

15. Freeman HJ, Berean KW. Resolution of paraneoplastic collagenous enterocolitis after resection of colon cancer. Can J Gastroenterol 2006;20:357-60.
Lymphocytic colitis may be asymptomatic; two studies $(1,31)$ have shown a frequency rate of $0.9 \%$ for lymphocytic colitis in routine colonoscopic biopsies of asymptomatic patients. Therefore, it is conceivable that the prevalence of histopathological changes of lymphocytic colitis is higher once asymptomatic individuals are accounted for. The risk for latent disease may lower the threshold for taking biopsies during screening colonoscopy, especially for those with other autoimmune conditions such as celiac disease. It is also suggested that the association between drugs and lymphocytic colitis may be mediated by activation of a latent disease process.

\section{SUMMARY}

The present paper describes a patient with celiac disease who manifested with lymphocytic enterocolitis after resection for colon cancer. The case highlights the potential latency of lymphocytic colitis, and raises the possibility of an association between lymphocytic colitis and colon cancer. Further research to better delineate the association between lymphocytic colitis and colon cancer, and the possibility of latent disease will improve our understanding of the epidemiology and pathogenesis of, and investigations for, this condition.

16. Fernandez-Banares F, Salas A, Forne M, Esteve M, Espinos J, Viver JM. Incidence of collagenous and lymphocytic colitis: A 5-year population-based study. Am J Gastroenterol 1999;92:418-23.

17. Agnarsdottir M, Gunnlaugsson O, Orvar KB, et al. Collagenous and lymphocytic colitis in Iceland. Dig Dis Sci 2002;47:1122-8.

18. Koskela RM, Niemela SE, Karttunen TJ, Lehtola JK. Clinical characteristics of collagenous and lymphocytic colitis. Scand J Gastroenterol 2004:39:837-45.

19. Baert F, Wouters K, D'Haens G, et al. Lymphocytic colitis: A distinct clinical entity? A clinicopathological confrontation of lymphocytic and collagenous colitis. Gut 1999;45:375-81.

20. Pardi DS, Ramnath VR, Loftus EV Jr, Tremaine WJ, Sandborn WJ. Lymphocytic colitis: Clinical features, treatment, and outcomes. Am J Gastroenterol 2002;97:2829-33.

21. Freeman HJ. Familial occurrence of lymphocytic colitis. Can J Gastroenterol 2001;15:757-60.

22. Gillett HR, Freeman HJ. Prevalence of celiac disease in collagenous and lymphocytic colitis. Can J Gastroenterol 2000;14:919-21.

23. Fernandez-Banares F, Esteve M, Farré C, et al. Predisposing HLA-DQ2 and HLA-DQ8 haplotypes of coeliac disease and associated enteropathy in microscopic colitis. Eur J Gastroenterol Hepatol 2005;17:1333-8.

24. Wu TT, Hamilton SR. Lymphocytic gastritis: Association with etiology and topology. Am J Surg Pathol 1999;23:153-8.

25. Casserly I, Stevens FM, McCarthy CF. Carcinoma of the right side of the colon and celiac disease. Dig Dis Sci 1997;42:862-4.

26. Dickey W. Colon neoplasia co-existing with coeliac disease in older patients: Coincidental, probably; important, certainly. Scand J Gastroenterol 2002;37:1054-6.

27. Hopper AD, Leeds JS, Hurlstone DP, Hadjivassiliou M, Drew K, Sanders DS. Are lower gastrointestinal investigations necessary in patients with coeliac disease? Eur J Gastroenterol Hepatol 2005;17:617-21.

28. Chan JL, Tersmette AC, Offerhaus GJ, Gruber SB, Bayless TM, Giardiello FM. Cancer risk in collagenous colitis. Inflamm Bowel Dis 1999;5:40-3.

29. Bonderup OK, Folkersen BH, Gjersoe P, Teglbjaerg PS. Collagenous colitis: A long-term follow-up study. Eur J Gastroenterol Hepatol 1999;11:493-5.

30. Alikhan M, Cummings OW, Rex D. Subtotal colectomy in a patient with collagenous colitis associated with colonic carcinoma and systemic lupus erythematosus. Am J Gastroenterol 1997;92:1213-5.

31. Jaskiewicz K, Rzepko R, Adrych K, Smoczynski M. Microscopic colitis in routine colonscopies. Dig Dis Sci 2006;51:241-4. 


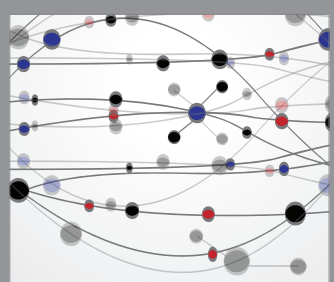

The Scientific World Journal
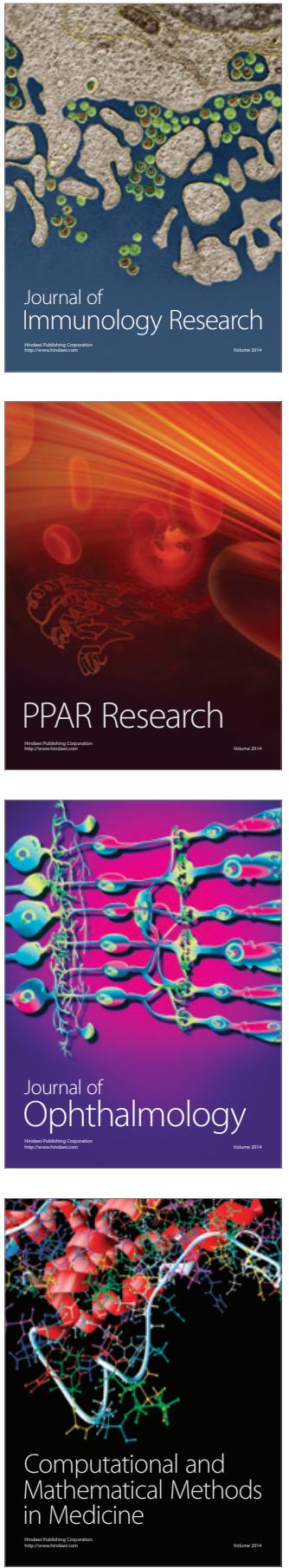

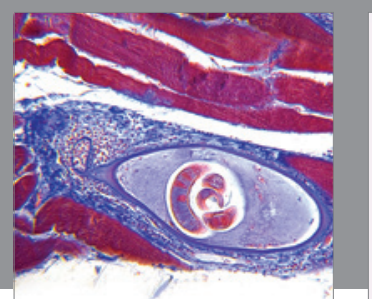

Gastroenterology Research and Practice

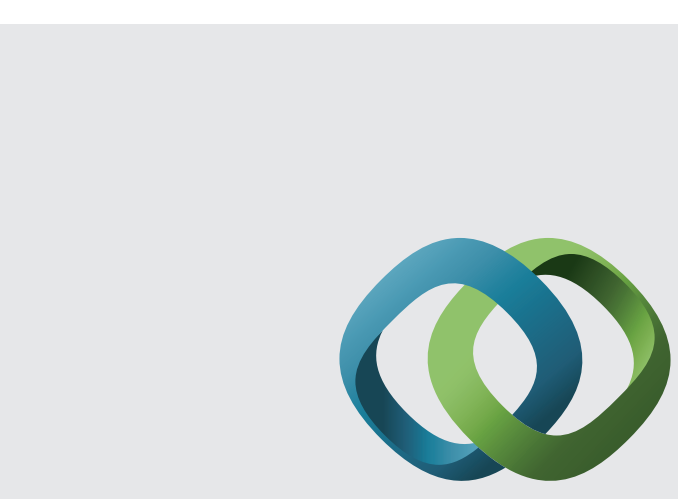

\section{Hindawi}

Submit your manuscripts at

http://www.hindawi.com
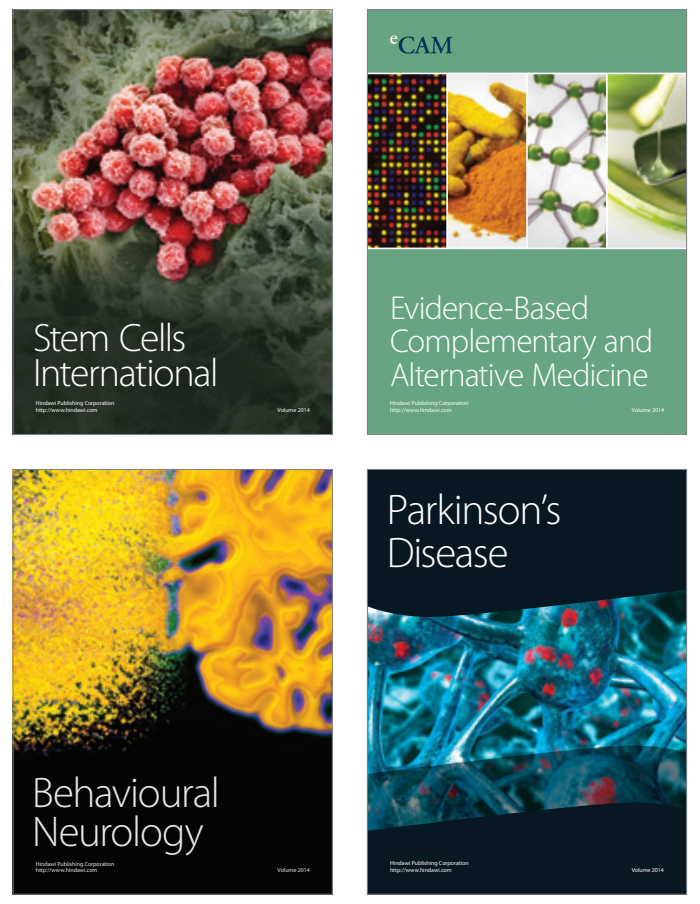
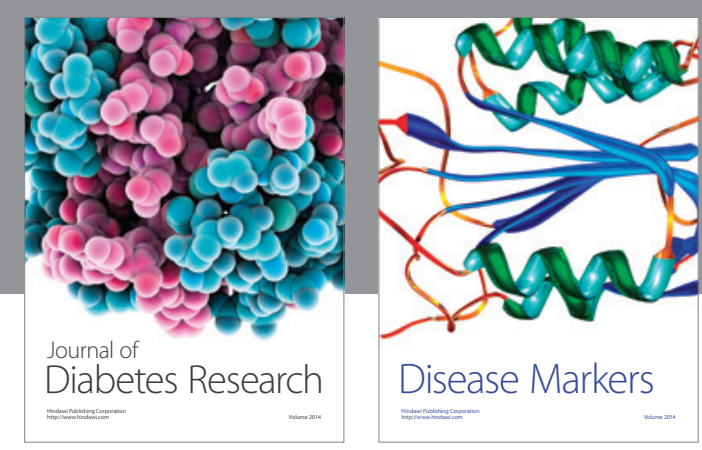

Disease Markers
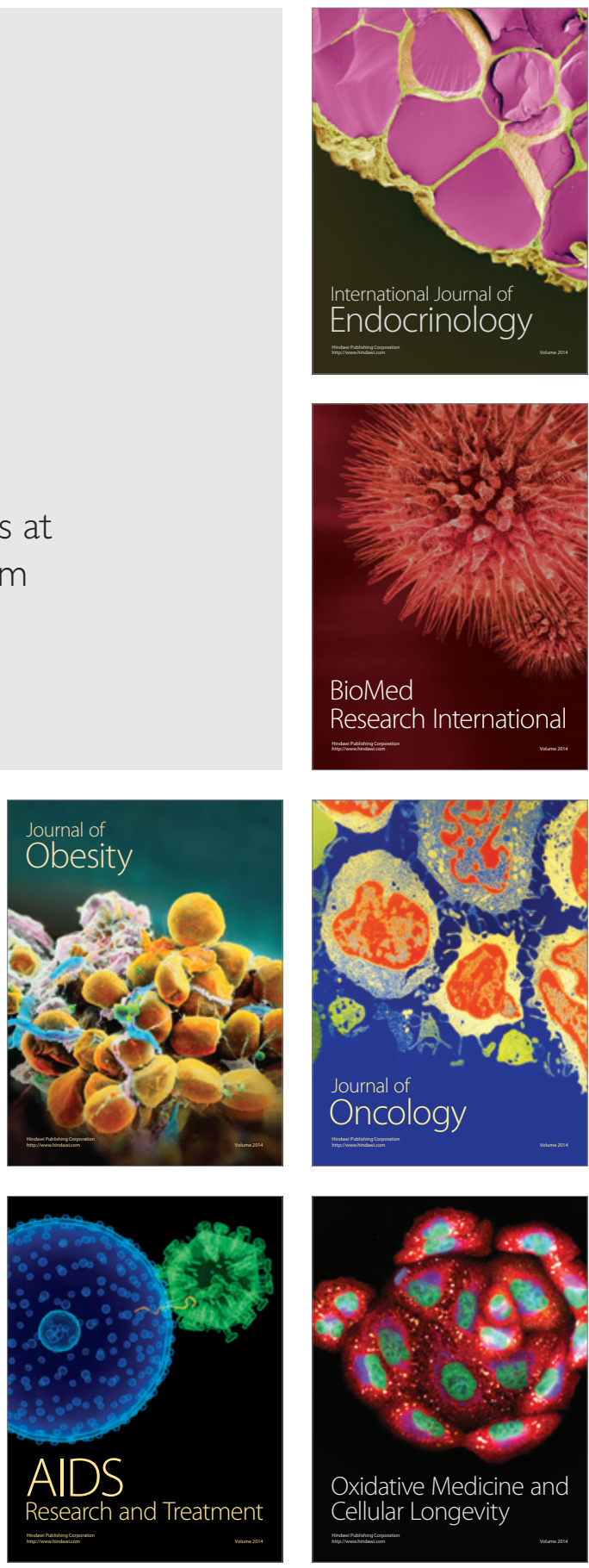